PART II. OTHER

DZIAŁ II. RÓŻNE

\title{
OPTIMIZED UPSTREAM THERAPY FOR MANAGING PATIENTS WITH POSTINFARCTION CARDIOSCLEROSIS ASSOCIATED WITH HYPERURICEMIA
}

\section{ZOPTYMALIZOWANA TERAPIA WSTĘPNA W CELU LECZENIA PACJENTÓW Z TWARDZINĄ SERCA ZWIĄZANĄ Z HIPERURYKEMIĄ}

\author{
Sofiya Lypovetska ${ }^{1(A, B, C D)}$, Olena Prokopovich ${ }^{1(B, F)}$, Mykola Shved $^{1(A, E)}$, Tetyana Boyko $^{1(D, F)}$
}

${ }^{1}$ I. Horbachevsky Ternopil State Medical University, Ukraine

Authors' contribution Wkład autorów:

A. Study design/planning zaplanowanie badań B. Data collection/entry zebranie danych C. Data analysis/statistics dane - analiza i statystyki D. Data interpretation interpretacja danych E. Preparation of manuscript przygotowanie artykułu F. Literature analysis/search wyszukiwanie i analiza literatury G. Funds collection zebranie funduszy
Tables: 1

Figures: 4

References: 21

Submitted: 2017 May 25

Accepted: 2017 Jun 07

\section{Summary}

Background. The recent epidemiological studies have shown that serum uric acid (SUA) is a risk factor for cardiovascular diseases and a negative prognostic marker for mortality in subjects with pre-existing heart failure.

Material and methods. 147 patients, $(59.2 \pm 0.8)$ years old, with postinfarction cardiosclerosis were included in this study. An evaluation of cardiohemodynamics, heart rhythm disturbances, lipid and purine metabolism's violation and systemic inflammation was performed before treatment and six months afterwards.

Results. An elevated SUA level was associated with the progression of postinfarction heart remodeling. Heterogenity of ventricular repolarization, decrease of heart rate variability, as well as high grade premature ventricular complexes were observed in these patients. Complex treatment with eprosartan provided a significant regress of left ventricle hypertrophy, achievement of target blood pressure levels, complete recovery from ventricular tachycardia, prevention of new-onset of atrial fibrillation. The use of fenofibrate resulted in reducing of total cholesterol, triglycerides, low density lipoproteins, SUA and main markers of systemic inflammation as well as an increase high density lipoproteins.

Conclusions. The use of eprosartan and fenofibrate is an optimized upstream strategy for managing patients with postinfarction cardiosclerosis associated with hyperuricemia

Keywords: postinfarction cardiosclerosis, hyperuricemia, inflammatory biomarkers

\section{Streszczenie}

Wprowadzenie. Ostatnie badania epidemiologiczne wykazały, że stężenie kwasu moczowego w surowicy krwi (SUA) jest czynnikiem ryzyka chorób sercowo-naczyniowych i stanowi ujemny wskaźnik prognostyczny przy klasyfikacji niewydolności serca i określania ryzyka śmiertelności. Materiał i metody. W badaniu uczestniczyło 147 pacjentów, $(59,2 \pm 0,8)$ lat, z zespołem stwardnienia kłębków poinfekcyjnych pozawałowych. Badania zostały przeprowadzone w dwóch etapach. W etapie pierwszym przeprowadzono ocenę parametrów hemodynamicznych, zaburzeń rytmu serca, pogorszenia metabolizmu lipidów i puryn oraz zapaleń ogólnoustrojowych przed leczeniem. Etap drugi obejmował ten sam układ badań sześć miesięcy później po zastosowaniu leczenia eprosartanem i fenofibratem.

Wyniki. Podwyższony poziom SUA ma ścisły związek z progresją przebudowy lewej komory serca. Zaobserwowano nierówność repolaryzacji komórkowej, spadek zmienności rytmu serca, a także wysokiej jakości przedwczesne kompleksy komorowe. W wyniku leczenia eprosartanem uzyskano istotne zmniejszenie przerostu lewej komory, docelowy poziom ciśnienia krwi, całkowite ustąpienie częstoskurczów komorowych. Leczenie eprosartanem zapobiegło również ponownemu pojawieniu się migotania przedsionków. Natomiast leczenie Fenofibratem spowodowało zmniejszenie poziomu cholesterolu całkowitego, trójglicerydów, lipoprotein o małej gęstości, SUA i głównych markerów zapaleń układowych, uzyskano natomiast zwiększenie poziomu lipoprotein o wysokiej gęstości.

Wnioski. Stosowanie eprosartanu i fenofibratu stanowi zoptymalizowaną strategię zapobiegawczą rozwoju chorób sercowo-naczyniowych u pacjentów z pozawałową miażdżycą serca związaną z hiperurykemią

Słowa kluczowe: twardzina serca, hiperurykemia, biomarkery zapalne

\section{Introduction}

The role of serum uric acid (SUA) in the process of atherosclerosis and atherothrombosis is controversial. The recent epidemiological studies (NHANES I, Honolulu Heart study, the MONICA/CORA Study Cohort, PIUMA, SHEP, Syst-China, etc.) have shown that SUA may be a risk factor for cardiovascular diseases and a negative prognostic

Lypovetska S, Prokopovich O, Shved M, Boyko T. Optimized upstream therapy for managing patients with postinfarction cardiosclerosis associated with hyperuricemia. Health Problems of Civilization. 2017; 11(2): 109-116. doi: 10.5114/hpc.2017.69032.

Address for correspondence / Adres korespondencyjny: Sofiya Lypovetska, I. Horbachevsky Ternopil State Medical University, m.Voli, 1, 46001 Ternopil, Ukraine, e-mail: sofiya.lypovetska@gmail.com, phone: +380 352524492

Copyright: (C) 2017 Pope John Paul II State School of Higher Education in Biała Podlaska, Sofiya Lypovetska, Olena Prokopovich, Mykola Shved, Tetyana Boyko. This is an Open Access journal, all articles are distributed under the terms of the Creative Commons Attribution-NonCommercial-ShareAlike 4.0 International (CC BY-NC-SA 4.0) License (http://creativecommons.org/licenses/by-nc-sa/4.0/), allowing third parties to copy and redistribute the material in any medium or format and to remix, transform, and build upon the material, provided the original work is properly cited and states its license. 
marker for mortality in subjects with pre-existing heart failure [1,2,3,4,5,6]. According to the WHO experts' recommendations, hyperuricemia is considered to be a component of metabolic syndrome $[7,8,9,10,11,12]$.

However, the influence of hyperuricemia on the increase of post-infarction remodelling of the heart, the onset of arrhythmia or development of heart failure is not completely defined. The same pertains to the efficiency of hypouricemic drugs [13]. The LIFE study showed that a decrease in SUA was associated with better long-term results in patients who were treated with losartan, as compared to those who took atenolol [14]. In addition, a meta-analysis of seven randomized trials (TRACE, SOLVD, ValHeFT, CHARM, etc.) demonstrated that treatment with ACE inhibitors and angiotensin-receptor blockers reduced the risk of atrial fibrillation (AF) and sudden cardiac death due to left ventricular hypertrophy regression, provided protection against atrial enlargement and supraventricular arrhythmias, as well as affected endothelial function, risk biomarkers and vascular remodelling $[15,16,17]$.

Also, an important prerequisite for reducing of arrhythmogenesis is a complex correction of atherogenesis. The presence of combined dyslipidemia, hypertrigliceridemia combined with hyperuricemia in patients after myocardial infarction demands additional assignments of fibrates $[18,19,20]$.

Objective: The study was undertaken to find out disturbances in cardiohaemodynamics, heart rhythm, lipid, purine metabolism and systemic inflammation, as well as the efficiency of upstream therapeutic strategies with eprosartan and fenofibrate in patients with postinfarction cardiosclerosis, associated with hyperuricemia.

\section{Material and methods}

The study was conducted in the Cardiology Department of Ternopil University hospital and involved 147 patients with post-infarction cardiosclerosis (106 men and 41 women) aged (59.2 \pm 0.8 ) years. The diagnosis was established by confirming the presence of myocardial infarction in anamnesis, clinical signs, ECG, including retrospective analysis, Echocardioscopy and the absence of myocardial necrosis markers.

The exclusion criteria included: acute coronary syndrome within the last 3 months, postinfarction cardiosclerosis within the first 6 months, severe renal and hepatic failure, exacerbation of chronic and acute inflammatory diseases, secondary hypertension, hemodynamically significant valvular heart disease, heart failure IV functional class.

Depending on the presence of hyperuricemia, all patients were preliminary stratified into 2 groups. Group I included 106 patients with postinfarction cardiosclerosis, combined with hyperuricemia $(0.59 \pm 0.06) \mathrm{mmol} / \mathrm{l}$ and group II - 41 patients with normal level of SUA (0.32 \pm 0.05$) \mathrm{mmol} / \mathrm{L}$. A comparative evaluation of atherosclerosis risk factors, medical history, disorders of cardiac hemodynamics, heart rhythm disturbances, lipid metabolism, markers of systemic inflammation was performed.

In order to determine the efficiency of upstream therapeutic strategies of postinfarction cardiosclerosis, associated with hyperuricemia, the patients were divided into 4 groups: group I included 30 patients who underwent standard treatment according to the Guidelines of European Cardiology Association, group II - 25 patients who instead of ACE inhibitors took eprosartan 600 mg once daily, group III - 25 patients who, in addition to the standard treatment, were prescribed with fenofibrate $200 \mathrm{mg}$ daily, group IV - 26 patients who took eprosartan and fenofibrate. Patients of all groups were comparable in age, sex, degree of metabolic disorders and the level of postinfarction changes. All clinical, laboratory and instrumental examination was performed before the treatment and 6 months later. The treatment efficacy was evaluated according to the degree of normalization of clinical signs, processes of cardiac remodeling, arrhythmogenesis, atherogenesis with the assessment of lipids, SUA and markers of systemic inflammation.

Cardiac hemodynamical disorders were detected by echocardioscopy using the standard method "Aloka SSD2000". The myocardial mass (MM) of the left ventricle (LV) was calculated by the Penn Convention formula. Thanks to Doppler technique, maximal flow velocities of early (E) and late (A) filling, their ratio E/A, deceleration time of early diastolic filling (DecT), time of isovolumic relaxation of LV (IVRT) were assessed.

The arrhythmias were assessed in Holter ECG monitoring, performed on "Kardiotechnika-04". The duration of Q-T interval, its dispersion (Q-Td), and Q-Tc were determined. The heart rate variability (HRV) was studied on the basis of the analysis of the time (SDANN, SDNN, SDNNidx, RMSSD, pNN50\%) and spectral (VLF, LF, HF, nHF) indices.

Lipid metabolism was studied by determining the level of total cholesterol (TC), triglcerides (TG), cholesterol of high density lipoproteins (HDL ), cholesterol of low density lipoproteins (LDL). SUA was determined by the photometric method, cholesterol of lipoproteins of very low density (VLDL) - by W. T. Friedwald formula. Markers of systemic inflammation - C-reactive protein (CRP), interleukin-1 (IL-1) and tumor necrosis factor $-\alpha$ (TNF- $\alpha$ ) were identified in an immune-enzyme analysis.

The results are presented as mean \pm standard error. The differences between comparable groups were examined by 2-tailed Student t test. The Spearman's rank correlation was used to establish the existence and strength of relationships between different values. A criterion for statistical confidence of $\mathrm{p}<0.05$ was adopted.

The research was conducted in accordance with the Convention on Human Rights and Biomedicine developed by the Council of Europe, Helsinki Declaration, and the recommendations of Bioethics Committee of the National Academy of Medical Sciences of Ukraine. 


\section{Results and discussion}

An important step of clinical examination of patients with postinfarction cardiosclerosis included a comparative analysis of risk factors and their stratification dependent on the presence of hyperuricemia. Such modified atherosclerosis risk factors as dyslipidemia, obesity, diabetes mellitus, arterial hypertension $(\mathrm{AH})$ were definitely more often observed in patients with hyperuricemia $(\mathrm{p}<0.01)$. According to the IDF criteria, metabolic syndrome was identified 8.3 times more frequently in patients with elevated SUA level than with normal (60.5\% vs. 7.3\%). Table 1 presents correlation of SUA level with risk factors of atherosclerosis.

Table 1. Correlation of serum uric acid with risk factors of atherosclerosis

\begin{tabular}{|c|c|c|}
\hline Index & r & p \\
\hline Age & 0.09 & $<0.05$ \\
\hline Body mass index, $\mathrm{kg} / \mathrm{m}^{2}$ & 0.36 & $<0.01$ \\
\hline Waist circumference, sm & 0.50 & $>0.01$ \\
\hline Index waist/hip & 0.14 & $<0.01$ \\
\hline Systolic BP, $\mathrm{mm} \mathrm{Hg}$ & 0.25 & $>0.05$ \\
\hline Diastolic BP, mm Hg & 0.09 & $<0.05$ \\
\hline Hyperglicemia, mmol/l & 0.22 & $<0.01$ \\
\hline TC, $\mathrm{mmol} / \mathrm{l}$ & 0.40 & $<0.01$ \\
\hline HDL, $\mathrm{mmol} / \mathrm{l}$ & -0.46 & $<0.01$ \\
\hline TG, $\mathrm{mmol} / \mathrm{l}$ & 0.47 & $<0.01$ \\
\hline LDL, $\mathrm{mmol} / \mathrm{l}$ & 0.40 & $<0.01$ \\
\hline VLDL, $\mathrm{mmol} / \mathrm{l}$ & 0.50 & \\
\hline
\end{tabular}

Patients with hyperuricemia compared with patients with normal level of SUA, had Q-wave myocardial infarction in anamnesis (61.3\% vs. $17.1 \%$ ), mostly anterior localition (53.8\% vs. 28.6\%). Pronounced hemodynamic impairments and occurrence of congestive heart failure occurred 4.6 times more often in patients with hyperuricemia.

The patients with an increased SUA compared to those with normouricemia, had a significantly increased end-diastolic dimension of LV (LV EDD) by 11.6\%, thickness of the interventricular septum (IVST) - by $22.9 \%$, the thickness of posterior wall (PWT) by 20.3\%, MM LV - 37.7\%, mass index of left ventricular (LVMI) $-33.3 \%$ (p<0.01). It was established that with increasing SUA, LVMI was also higher (Fig. 1).

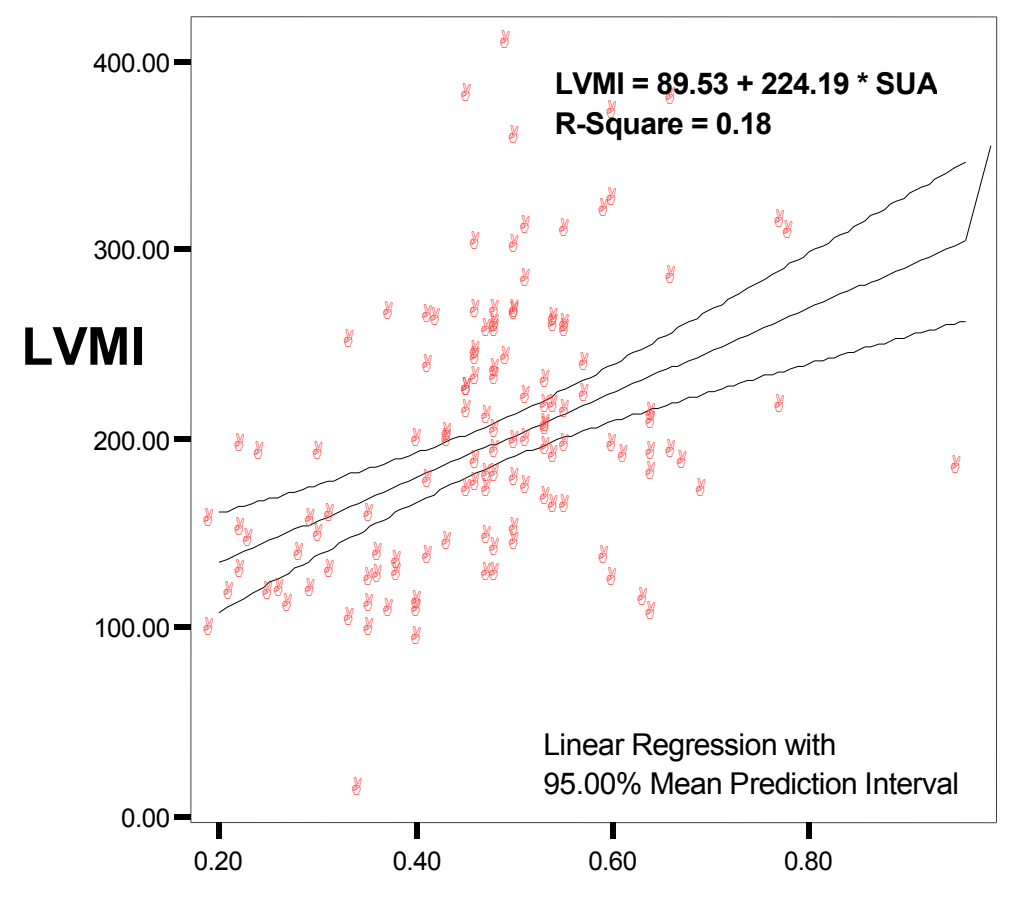

SUA

Figure 1. A linear relationship of uric acid with myocardial mass index of left ventricle in patients with postinfarction cardiosclerosis 
The analysis of $\mathrm{LV}$ remodeling in patients with hyperuricemia compared to patients with normouricemia showed that concentric (56.6\% vs $26.8 \%$ ) and eccentric ( $40.6 \%$ vs $31.7 \%$ ) hypertrophy dominated.

The patients with hyperuricemia compared to patients with normouricemia more often showed diastolic dysfunction of LV (85.8\% vs. 36.6\%): relaxation type (19.8\% vs. 9.7\%), pseudonormal type (67.0\% vs. 26.8\%). Restrictive type was identified only in patients with elevated SUA (13.2\%). Systolic dysfunction was diagnosed in 15 (14,2\%) patients with hyperuricaemia and $5(12.2 \%)$ - with normouricemia. A positive significant correlation of SUA with the size of the left atrium (LA), right ventricle, IVST, EDD LV, MM LV, IMM LV ( $\mathrm{r}=0.30-0,49, \mathrm{p}<0.01$ ), and PWT LV ( $\mathrm{r}=0.22$, $\mathrm{p}<0.05)$ and indices of diastolic function : E, DTE $(r=0.26-0.61, p<0.01), E / A(r=0.21, p<0.05)$ was found.

An analysis of arrhythmias showed no significant difference between the frequency of supraventricular arrhythmias (AF, supraventricular extrasystoles (SES)) in patients with high and normal level of SUA. The differences was found among ventricular arrhythmias: ventricular extrasystols (VES) II - class IV by B. Lown- M. Wolf and conduction disturbances in His-Purkinje system were recorded significantly more often (2.5 times) in patients with hyperuricemia

Patients with high SUA level had significantly higher $(42.8 \mathrm{~ms}$ ) Q-Td, compared with patients with normouricemia $(\mathrm{p}<0.05)$. The assessment of day rhythms of Q-T showed that duration of Q-T was higher at night than during the day by $20.8 \mathrm{~ms}$, and Q-Td - $20.0 \mathrm{~ms}$. A correlation between the value of Q-Tc and episodes of unstable ventricular tachycardia was found $(\mathrm{r}=0.42, \mathrm{p}<0.05)$.

The assessment of HRV in patients with postinfarction cardiosclerosis showed that all time indices were reduced, regardless of the presence of hyperuricemia. However, in patients with large myocardial damage, time indices were even smaller and critically low - in patients with LV aneurysm, complicated by congestive heart failure $(\mathrm{p}<0.01)$. With the deterioration of the clinical conditions, an average heart rate was significantly increased, directly indicated the increase of sympathetic tone. However, the increase of sympathoadrenal influences did not result in an increase of the LF spectrum, but was accompanied by its decline.

The lipid profile of patients with hyperuricemia was characterized by significantly higher indices of TC by, $20.9 \%$, TG - by $38.1 \%$, LDL - by 31.8\% and lower HDL - 32.8\% ( $<<0.01$ ) in comparison with patients with normal SUA level. Combined dyslipidemia (67.9\% vs. 2.4\%) and hypertrigliceridemia (6.6\% vs. 2.4\%) were dominated among them.

However, patients with hyperuricemia had significantly increased markers of systemic inflammation, particularly CRP - by 71.4\%, IL-1 - 49.9\%, TNF $\alpha-76.2 \%$ (p<0.01) compared to patients with normouricemia. A correlation was established between increased levels of SUA and CRP ( $r=0.7, p<0.01)$, and TNF- $\alpha(r=0.8, p<0.01)$, and IL-1 ( $r=0.7$, $\mathrm{p}<0.01$ ). In addition, it was shown that with increasing of SUA, increasing of CRP, IL-1, TNF- $\alpha$ was observed, which confirms the role of hyperuricemia in systemic inflammatory response (Fig. 2, 3, 4).

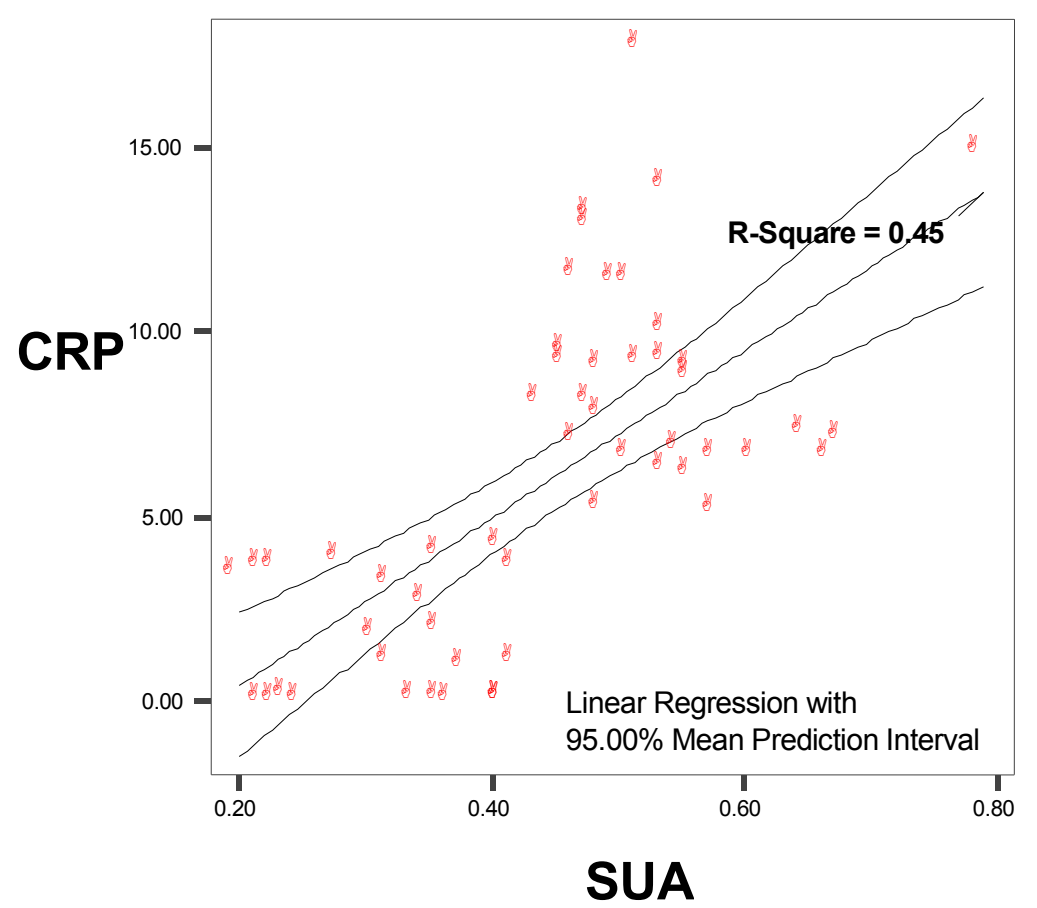

Figure 2. A linear relationship of uric acid with C-reactive protein in patients with postinfarction cardiosclerosis 


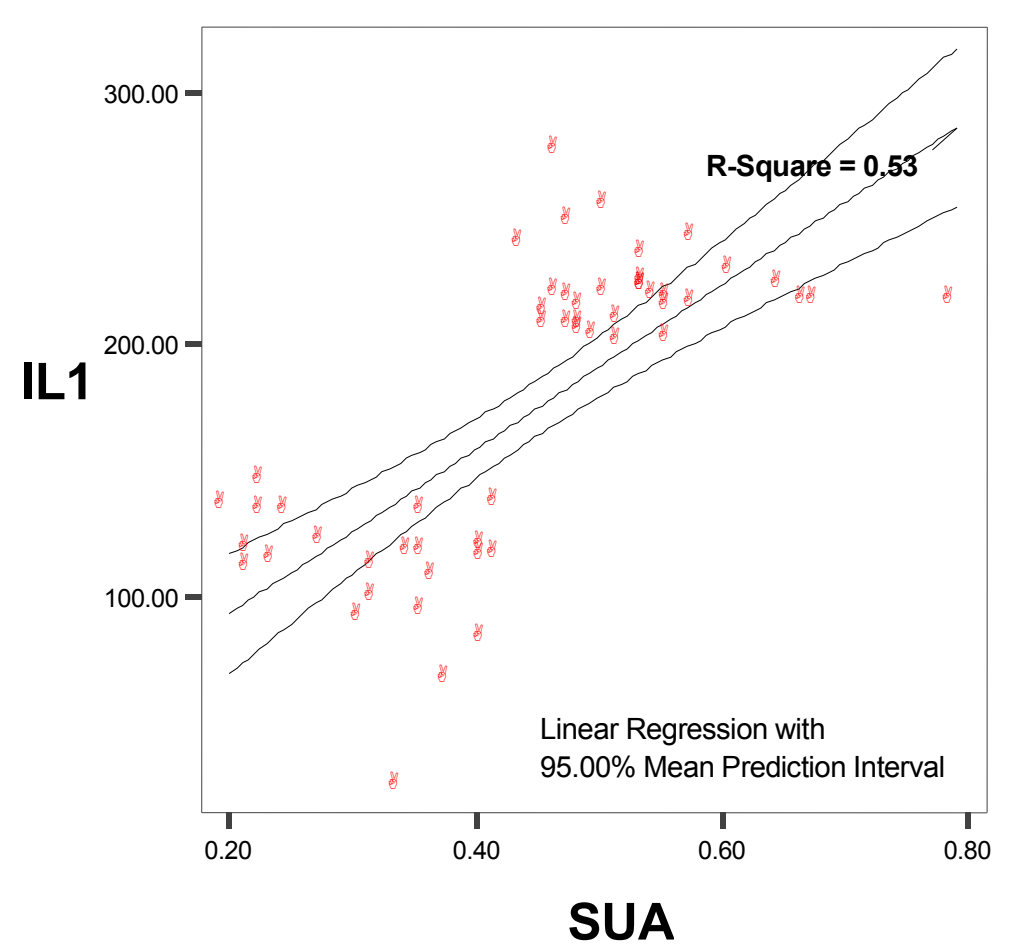

Figure 3. A linear relationship of uric acid with Interleukin 1 in patients with postinfarction cardiosclerosis

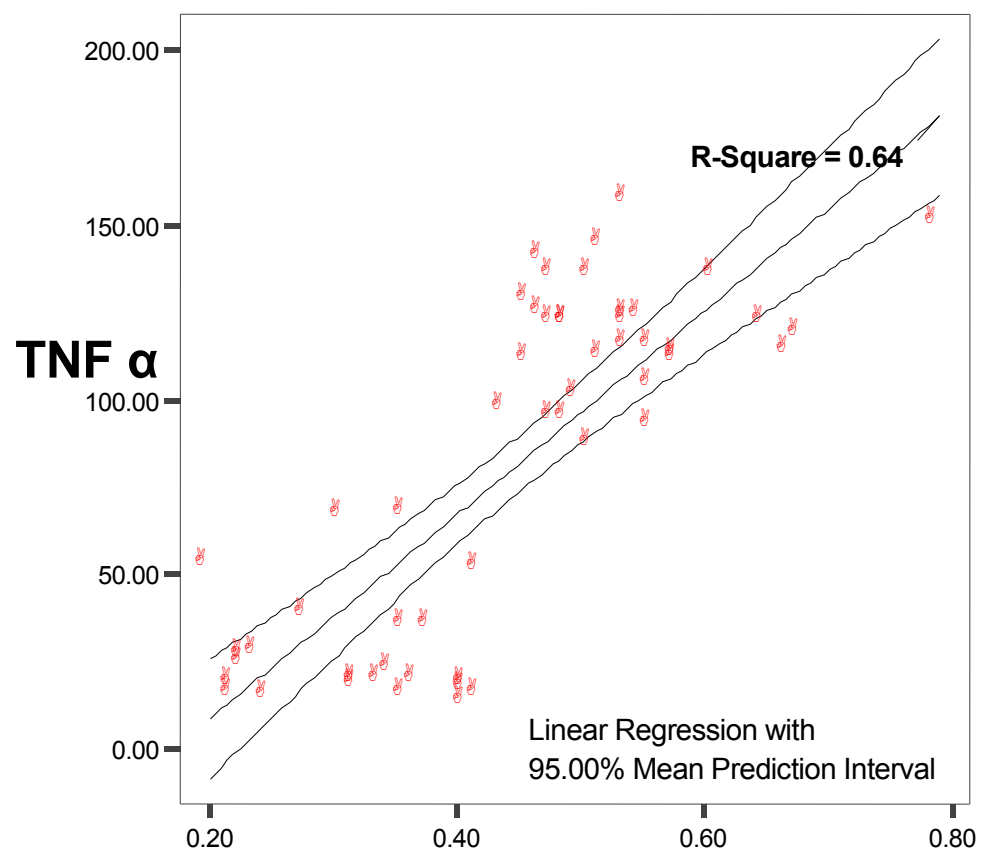

\section{SUA}

Figure 4. A linear relationship of uric acid with tumor necrosis factor $\alpha$ in patients with postinfarction cardiosclerosis

The standard treatment contributed to the improvement in $46.7 \%$ patients of group I, mainly due to the reduction of heart failure. However, the target BP levels were achieved only in 36.8\% of the patients. After 6 months, a significant decrease of LV MM by $10.9 \mathrm{~g}$ and LV MI by $9.5 \mathrm{~g} / \mathrm{m}^{2}(\mathrm{p}<0.05)$ were defined, testifying reduction of LV hypertrophy (IVST on $3.5 \%$ and PWT LV on $5.6 \%(\mathrm{p}<0.05)$ ). However, the relative wall thickness did not change, which proved the prevalence of concentric hypertrophy in these patients. Also, the ejection fraction (EF) LV did not changed significantly.

The results of spectral analysis of HRV showed that most patients had an increased sympathetic tone. In $53.3 \%$ patients, SDNN remained at the level less than 100 ms. In addition, they had VES of high grades, no significant dynamics in the duration Q-T interval. 
The standard treatment provided a reduction of most atherogenic fractions of lipids, except TG and SUA, but did not lead to sufficient growth of HDL. The presence of hypertrigliceridemia and hyperuricemia are negative factors that do not provide adequate balance in the metabolism of purines and lipids.

A 6-month treatment with eprosartan contributed to the clinical improvement in $80.0 \%$ patients of group II due to reduction of heart failure and adequate treatment of hypertension. Target BP was achieved in $60.0 \%$ of patients. LV MM was decreased by $15.6 \mathrm{~g}$, MM LV $-10.5 \mathrm{~g} / \mathrm{m}^{2}$ and LVEF was increased by $3.7 \%(\mathrm{p}<0.01)$, decreasing of $\mathrm{E}$ by $13.0 \mathrm{sm} / \mathrm{s}(14.1 \%)$ and the growth of A by $18.1 \mathrm{sm} / \mathrm{s}(23.6 \%)(\mathrm{p}<0.01)$ were detected. The ratio $\mathrm{E} / \mathrm{A}$ was decreased by 0.32 units $(26.4 \%)(\mathrm{p}<0.01)$, and DecT was increased by $3.5 \mathrm{~ms}(1.8 \%)(\mathrm{p}<0.05)$. All these changes indicated an improvement in diastolic LV filling and, consequently, a correction of diastolic dysfunction.

An average heart rate was decreased by $13.1 \%$ in the afternoon and $19.7 \%$ at night, which was accompanied by an increased circadian index. The total number of VES was decreased by $73.7 \%(\mathrm{p}<0.01)$, and the frequency of the episodes of the paired VES - 84.4\% ( $<<0.05)$, SES - by 70.6\% ( $<<0.01)$, and paired SES - by $70.2 \%(\mathrm{p}<0.01)$, and group - by_41.4\% (p<0.05). At the same time, we observed a significantly increased SDNN on $12.5 \%$, SDNNidx - 22.1\%, SDANN $-10.6 \%$, pNN50\% - 24.0\%, nHF - 18.0\% and reduction of VLF - by $21.8 \%, \mathrm{LF}-15.2 \%(\mathrm{p}<0.01)$.

The positive dynamics in the duration of Q-T interval was observed, in particular the average Q-T duration was significantly decreased by $2.6 \mathrm{~ms}(\mathrm{p}<0.05)$, maximum - by $8.4 \mathrm{~ms}(\mathrm{p}<0.01)$, and average $\mathrm{Q}-\mathrm{Tc}-3.0 \mathrm{~ms}(\mathrm{p}<0.05)$ and maximum - by $11.2 \mathrm{~ms}$, Q-Td - by $15.2 \mathrm{~ms}(\mathrm{p}<0.01)$.

The dynamics of clinical manifestations of the disease, indices of cardiac hemodynamics, arrhythmias, BP in patients of group III, whose treatment included fenofibrate, were similar as in the patients of group I. However, there was observed a significant improvement of lipid and purine metabolism: the contents of serum CH decreased by $26.6 \%$, TG 39.4\%, LDL - 38.4\%, VLDL -39.6\%, while HDL increased by 30.1\% ( $\mathrm{p}<0.01)$. The level of SUA was decreased by 37.0\% $(p<0.01)$. The content of CRP decreased by $76.3 \%$, IL-1 $-46.4 \%$, TNF- $\alpha-56.3 \%(p<0.01)$. The correlation analysis showed no relationship between the decrease of lipid atherogenic fractions and CRP ( $r=-0.08, p=0.5)$, TNF- $\alpha(r=-0.015$, $\mathrm{p}=0.2)$, IL-1 ( $\mathrm{r}=-0.18, \mathrm{p}=0.2)$, indicating independence of lipid lowering and anti-inflammatory effects of fenofibrate.

The inclusion of eprosartan and fenofibrate in the treatment contributed to the improvement of the clinical status in $88.5 \%$ of the subjects of group IV due to reduction of arrhythmias, heart failure and control of hypertension. Target BP levels were achieved in $85.7 \%$ patients. The most prominent reduction of LV hypertrophy $\left(14.3 \mathrm{~g} / \mathrm{m}^{2}(6.6 \%)\right.$ and significant $(\mathrm{p}<0.05)$ decrease in the size of LA $(8.0 \%)$ was achieved in group IV. A significant increase of LVEF by $6.2 \%$ $(\mathrm{p}<0.01)$ was observed.

The decrease in the average day heart rate by $11.3 \%$ and $12.2 \%$ at night were found, which was accompanied by normalization of the circadian index. The total number of VES was decreased by $66.4 \%(\mathrm{p}<0.01)$, and complete elimination of episodes of ventricular tachycardia was achieved, polymorphic, early and paired extrasystoles were decreased by $94.1 \%$. In addition, the total number of SES were reduced by $74.2 \%(\mathrm{p}<0.01)$, and pair - by $67.2 \%(\mathrm{p}<0.01)$, and group $-50.9 \%(p<0,05)$. During the follow-up, new paroxysms of atrial fibrillation and supraventricular tachycardia in patients of this group were not detected. The average duration of Q-T interval was significantly decreased by $9.3 \mathrm{~ms}$ $(\mathrm{p}<0.05)$, the maximum Q-Tc $-16.5 \mathrm{~ms}(\mathrm{p}<0.01)$, and Q-Td $-17.0 \mathrm{~ms}(\mathrm{p}<0.01)$. At the same time, HRV was significantly increased: SDNN - by $19.7 \%$, SDANN - 29.1\% , pNN50\% - 26.9\% ( $<<0.01)$, and RMSSD - 18.8\% ( $<<0.05) . V L F$ and LF were decreased by $29.6 \%$ and $23.2 \%$ respectively, $\mathrm{HF}$ and $\mathrm{nHF}$ were increased on $14.8 \%$ and $25.1 \%(\mathrm{p}<0.01)$.

Sustained lipid lowering, hypouremic and pleiotropic effects were achieved due to the treatment in group IV: the level of TC was decreased by $21.1 \%$, TG - 44,2\%, LDL- 30.1\%, VLDL- 43.8\%, SUA-37.5\%, the level of HDL was increased by_30.7\% (p<0.01). A significant reduction of CRP by $71.2 \%$, TNF- $\alpha-69.0 \%$, IL-1 $-47.1 \%(\mathrm{p}<0,01)$ were found.

Summarizing the obtained results, optimized upstream treatment with eprosartan and fenofibrate effectively influence the process of systemic atherogenesis, which is the pathogenic background of coronary artery disease, correcting the combined dyslipidemia, hyperuricemia, reducing of systemic inflammation. Long-term blockade of the renin-angiotensin and sympathoadrenal systems contributes to the reduction of pathological post-infarction remodelling, arrhythmogenesis and control of arterial hypertension.

\section{Conclusions}

1. Hyperuricemia was associated with intensive post-infarction heart remodelling, manifested in an increase of myocardial mass of left ventricle $\left((220.9 \pm 6.9) \mathrm{g} / \mathrm{m}^{2}\right)$ and violation of its geometry: concentric $(56.6 \%)$ and eccentric (40.6\%) hypertrophy with diastolic dysfunction (relaxation type $-19.8 \%$, pseudonormal $-67.0 \%$ and restrictive $-13.2 \%$ ). Between elevated uric acid levels, parameters of intracardiac hemodynamics and diastolic function significant correlation relationship were found $(r=0.4-0.6, p<0.01)$.

2. Patients with postinfarcion cardioscrerosis, associated with hyperuricaemia, were characterized by heterogeneity of ventricular repolarisation (dispersion of Q-T more than $70 \mathrm{~ms}$ ), total vegetative imbalance with a predominance of sympathetic tone and reduction of time parameters of heart rate variability (SDNN less than 100 
$\mathrm{ms}$ ). At the same time, they had a significantly (2.5 times) more often recorded ventricular extrasystoles class II-IV by B. Lown- M. Wolf and conduction disturbances in the system. His-Purkinje, compared with patients with normouricemia.

3. Patients with postinfarction cardiosclerosis, associated with hyperuricaemia, in $70.9 \%$ cases had combined dyslipidemia with hypertrigliceridemia, low levels of high-density lipoproteins, combined with an increased activity of markers of systemic inflammation. The close correlation was established between increased levels of uric acid and C-reactive protein $(r=0.7, p<0.01)$, tumor necrosis factor $\alpha(r=0.8, p<0.01)$, and interleukin $-1(r=0.7, p<0.01)$.

4. Eprosartan, included in the standard medical treatment, contributed to a significant reduction of left ventricular hypertrophy (myocardial mass index decreased by $14.3 \mathrm{~g} / \mathrm{m}^{2}$ ) and an increase of ejection fraction from $(46.2 \pm 1.2) \%$ to $(52.4 \pm 1.1) \%$. Circadian index, heart rate were normalized, the overall number of ventricular extrasystoles were decreased by $66.4 \%$, episodes of ventricular tachycardia, polymorphic extrasysytoles were eliminated, the length of Q-Tc interval and Q-T dispersion were decreased by $21.1 \%$ and heart rate variability was increased. Target levels of blood pressure were achieved in $85,7 \%$ patients.

5. Fenofibrate, included in in the standard medical treatment, provided sustainable hypouremic, lipid-lowering and pleiotropic effects, which were manifested by lowering the total cholesterol by $21.1 \%$, triglcerides $-44.2 \%$, low-density lipoproteins $-30.1 \%$, serum uric acid $-37.5 \%$, C-reactive protein $-71.2 \%$, of tumor necrosis factor $\alpha-69.0 \%$, interleukin I $-47.1 \%$ and an increase of high density lipoproteins - on $30.7 \%$.

\section{References:}

1. Capuano V, Marchese F, Capuano R, Torre S, Iannone AG, Capuano E, et al. Hyperuricemia as an independent risk factor for major cardiovascular events: a 10-year cohort study from Southern Italy. J Cardiovasc Med (Hagerstown). 2017 Mar; 18(3): 159-164. doi: 10.2459/JCM.0000000000000347.

2. Dutta A, Henley W, Pilling LC, Wallace RB, Melzer D. Uric acid measurement improves prediction of cardiovascular mortality in later life. J Am Geriatr Soc. 2013; 61: 319-326.

3. Khan A, Mohammad HS, Khan S, Shamim U, Arshad S. Serum Uric Acid level in the severity of Congestive Heart Failure (CHF). Pak J Med Sci. 2017 Mar-Apr; 33(2): 330-334. doi: 10.12669/pjms.332.11779.

4. Min L, Xiaolan H, Yingli F, Kun L, Xiaowei Z, Wenshang H, et al. Hyperuricemia and the risk for coronary heart disease morbidity and mortality a systematic review and dose-response meta-analysis. Scientific report. 2016; 6: 9520; doi: 10.1038/srep19520.

5. Lypovetska S. Role of uric acid in progression of heart remodeling in patients after myocardial infarction: liaison between metabolic profile and subclinical inflammation. European Journal of Heart Failure. $2017 ; 19$ (Issue Supplement S1): 133.

6. Pascual-Figal DA, Hurtado-Martinez JA, Redondo B. Hyperuricemia and long-term outcome after hospital discharge in acute heart failure patients. Eur J Heart Fail. 2006; 9: 518-524.

7. Krishnan E, Kwoh CK, Schumacher HR, Kuller L. Hyperuricemia and incidence of hypertension among men without metabolic syndrome. Hypertension. 2007; 49: 298-303.

8. Kuwabara M, Niwa K, Hisatome I. Asymptomatic Hyperuricemia Without Comorbidities Predicts Cardiometabolic Diseases: Five-Year Japanese Cohort Study. Hypertension. 2017; Jun; 69(6): 1036-1044. doi: 10.1161/ HYPERTENSIONAHA. 116.08998. Epub 2017 Apr 10.

9. Mazza A, Lenti S, Schiavon L, Del Monte A, Danyelle M. Townsend D, Ramazzina E. Asymptomatic hyperuricemia is a strong risk factor for resistant hypertension in elderly subjects from general population. Biomed Pharmacother. 2017; 86: 590-594.

10. Savarese G, Ferri C, Trimarco B. Changes in serum uric acid levels and cardiovascular events: a meta-analysis. Nutr Metab Cardiovasc Dis. 2013; 23: 707-714.

11. Skak-Nielsen H, Torp-Pedersen C, Finer N, Caterson I, Van Gaal L, Philip T James. Uric acid as a risk factor for cardiovascular disease and mortality in overweight/obese individuals. PLoS One. 2013, 8: e59121

12. Viazzi F, Piscitelli P, Giorda C, Ceriello A, Genovese S, Russo G, et al. Metabolic syndrome, serum uric acid and renal risk in patients with T2D. PLoS One. 2017 Apr 19; 12(4): e0176058. doi: 10.1371/journal.pone.0176058. eCollection 2017.

13. Bove M, Cicero AF, Veronesi M. An evidence-based review on urate-lowering treatments: implications for optimal treatment of chronic hyperuricemia. Vasc Health Risk Manag. 2017; 13: 23-28.

14. Hoieggen A, Alderman MH, Kjeldsen SE, Julius S, Devereux RB, De Faire U, et al. The impact of serum uric acid on cardiovascular outcomes in the LIFE study. Kidney Int. 2004; 65: 1041-1049.

15. Anand K, Mooss An, Hee TT. Meta-analysis: inhibition of renin-angiotensin system prevents new-onset atrial fibraillation. Am Heart J. 2006; 152 (2): 217-222. 
16. Maharani N, Kuwabara M, Hisatome I. Hyperuricemia and Atrial Fibrillation. Int Heart J. 2016 Jul 27; 57(4): 395-9. doi: 10.1536/ihj.16-192. Epub 2016 Jul 11. Review

17. Petrella RJ, Gill DP, Berrou JP. Effect of eprosartan-based antihypertensive therapy on coronary heart disease risk assessed by Framingham methodology in Canadian patients with diabetes: results of the POWER survey, 2015 Mar 24; 8: 173-80. doi: 10.2147/DMSO.S79221.

18. Guang-zhong Liu, Ting-ting Hou, Yue Yuan, Peng-zhou Hang, Jing-jing Zhao, Li Sun, et al. Fenofibrate inhibits atrial metabolic remodelling in atrial fibrillation through PPAR- $\alpha /$ sirtuin 1/PGC-1 $\boldsymbol{\alpha}$ pathway. Br J Pharmacol. 2016 Mar; 173(6): 1095-1109.

19. Petersen TS, Madsen TV, Jespersen JB, Larsen A, Schmidt EB, Christensen JH Uric acid in patients with angiographically documented coronary heart disease. Acta Cardiol. 2006; 61(5): 525-529.

20. Spiga R, Marini MA, Mancuso E, Di Fatta C, Fuoco A, Perticone F, et al. Uric Acid Is Associated With Inflammatory Biomarkers and Induces Inflammation Via Activating the NF- $\kappa$ B Signaling Pathway in HepG2 Cells. Arterioscler Thromb Vasc Biol. 2017 Apr 13. pii: ATVBAHA.117.309128. doi: 10.1161/ATVBAHA.117.309128

21. Storhaug H, Norvik J, Toft I, O Eriksen B, Lochen ML, Zykova S, et al.Uric acid is a risk factor for ischemic stroke and all-cause mortality in the general population: a gender specific analysis from The Tromso Study. BMC Cardiovasc Disord. 2013,13: 115. 